\title{
Environmental Impact of Artesanal Mining of Barytes in Azara Area, Middle Benue Trough, Nigeria
}

\author{
${ }^{1}$ M.S. Chaanda, ${ }^{2}$ N.G. Obaje, ${ }^{2}$ A. Moumouni, ${ }^{2}$ N.G. Goki and ${ }^{3}$ U.A. Lar \\ ${ }^{1}$ Department of Earth Sciences, College of Sciences, \\ Federal University of Petroleum Resources, Effurun, Delta State, Nigeria \\ ${ }^{2}$ Department of Geology and Mining, Nasarawa State University-Keffi, Nigeria \\ ${ }^{3}$ Department of Geology and Mining, University of Jos, Nigeria
}

\begin{abstract}
The name Azara has become synonymous with artesanal mining of baryte in Nigeria. This activity turned into a lucrative business immediately after the abandonment of the mechanized method of mining in the $80 \mathrm{~s}$. Ever since then, the exploration of barite in Azara has been manual characterized by the use of primitive tools such as diggers and shovels usually on a small scale. Under this condition, certainly only the surface or near surface veins are exploited. Also, the conditions under which the local miners work is highly risky and could result in loss of lives and property. The exploitation is done indiscriminately either by individuals or groups. However, there appears to be some coordination in the manner in which each individual or groups go about the exploitation. The environmental impact is great. Apart from the devastation of arable farmland, very large and deep pits are left behind after exploitation which could form death traps. However, despite these environmental consequences, artesanal mining of barite has become a major occupation of the rural mining communities in and around Azara especially during the dry season when the farming activity has ended. The activity provides a major source of income and upliftment of the economic well-being of Azara community and environs. In the recent restructuring of the Ministry of Solid Minerals Development, a whole department on Artesanal and small Scale Mining (ASM) was created and charged with the responsibility to organize, support and promote ASM. Government therefore has the responsibility of encouraging the artesanal mining of barite at Azara through funding and ensuring that the practice is done with legal/regulatory framework and minimizing the adverse effects on the environment.
\end{abstract}

$\underline{\text { Key words: Azara, mining, baryte, environment, arable farmland, Nigeria }}$

\section{INTRODUCTION}

The Azara barite deposit is the most important barite occurrence in Nigeria where the defunct Nigerian Mining Corporation has confirmed a reserve of 730,000 ton. This reserve alone is enough to sustain the nation's demand for over 20 years (RMRDC, 1989). Hitherto, about 18 baryte veins measuring about $2 \times 1000 \mathrm{~m}$ were being mined under the supervision of the defunct Nigerian Mining Corporation. Thus, mechanized mining had been in practice for a long time in the Azara area.

Baryte occurs together with lead and zinc in hydrothermal veins in the Benue Trough spreading from the Gwana Zurak Azara Abakaliki belt (Offodile, 1976, 1989) prior to the establishment of the Ministry for Solid Mineral Development (MSMD) in 1995, not much emphasis was laid on the exploration of solid minerals especially in the Benue Trough. During the pre 1995 period, the exploration of minerals had remained the exclusive stock in trade of the artesanal miners to source local of buyers. The exact reserves and quantity exploited by the local miners are difficult to be estimated since exploitation has been haphazard. However, research by the Nigerian Mining Corporation (NMC) revealed a proven reserve of about 100,000 ton of good quality barite (Obaje et al., 2006) (Fig. 1).

In the Azara area, the Nigerian Mining Corporation mapped out about 18 major mineralized veins for exploitation but was abandoned in the 80 's. Artesanal miners consisting mainly of the poor villagers (women, men and youths including children) now besiege the entire area (Fig. 2). The mining methods include open cast (which involves the use of primitive tools such as diggers hoes, shovels, etc.) and underground tunneling and lotto and explosives are sometimes used. These risky artesanal mining methods are crude and often have grave and fatal consequences especially in cases where the dug out pits have gone to great depths. Presently,

Corresponding Author: U.A. Lar, Department of Geology and Mining, University of Jos, Nigeria 


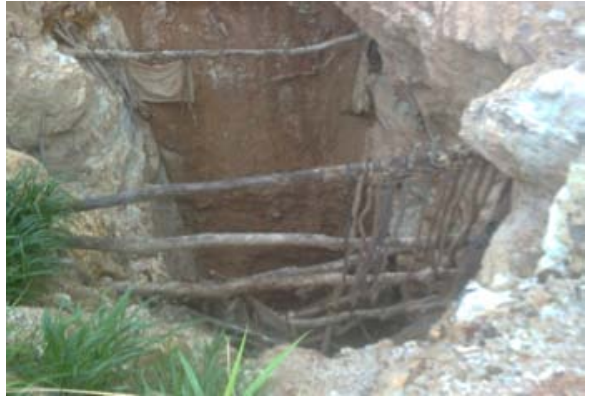

Fig. 1: Azara Baryte mine, NMC vein 2

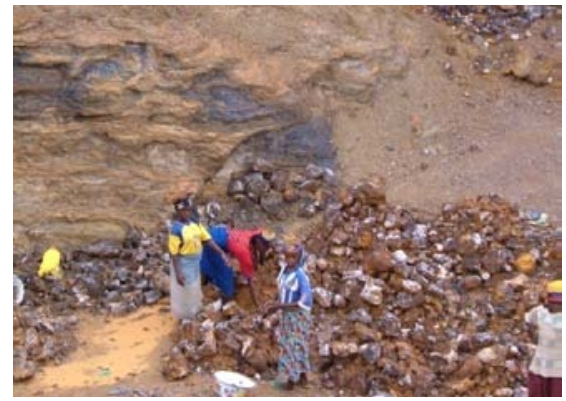

Fig. 2: The women folk are not left out in the execution of baryte extraction

most of the mining activities are concentrated around the NMC vein 17 and vein 18 . The excavations follow the veins along their strikes. This consists of hand sorting after the ore has been brought up from the trench through the use of bucket and rope. The reserve of mineralized barite in veins around the Azara area is estimated at 40,000 metric ton (Offodile, 1976) with $\mathrm{BaSO}_{4}$ content of $>80 \%$. The driving force sustaining the continued mining in the area is basically economic pressure from the poverty stricken villagers, lack of good jobs and the continued demand from the buyers. These forces give little or no regard to both the environmental and social effects of their operations. Apart from the environmental degradation caused by such mining, social vices like prostitution and drug abuse are rampant among the youths, women and men (ANNEX 1, MSMD in 2002). Also the high level of interaction of merchants could contribute to a rapid spread of diseases especially STDs and HIV/AIDS.

The abandoned mining ponds are in most cases filled with water. The miners and the local communities use water from such ponds for domestic purposes. There is possibility of element contamination of such water visibly from the composition of the exposed minerals or from external sources. The Azara area falls within the Benue depression with about seven months wet season, mean annual rainfall range of $120-150 \mathrm{~cm}$, relative humidity of about $60-60 \%$ and falls within the Guinea savannah vegetation belt. The major inhabitants of the region are the Aragos, the Koros and minor settlers such as the Hausas, the Tivs and the Kambaris.

\section{MATERIALS AND METHODS}

Brief history of mining in Nigeria: Organized mining in Nigeria started around 1939 through private owned foreign companies. The first legislation on mining was enacted in 1946 and was only reviewed in 1999. Both laws (1946 and 1999) have no provision for artesanal mining. The collapse of big mining companies in the early 70 s led to massive unemployment of mine workers without any means of livelihood. Many of them went into illegal mining activities to survive.

Increased global demand for solid minerals and the introduction of SAP (Structural Adjustment Programme) created ready export markets for products of illegal mining activities; this also led to the emergence of middlemen and mineral smugglers. The official response to these phenomena was wild and not sustained. Illegal mining activities have continued to flourish uncensored, due also to lack of alternative gainful employment. Government can no longer ignore these illegal activities because of the huge revenue loss and the attendant environmental degradation as well as other social problems.

Aims and justification for the study: The ban on baryte importation by the federal government has made it difficult in meeting the current demand estimated at 10 million ton year ${ }^{-1}$ (Aliyu et al., 1996). The bulk of this demand is provided by artesanal mining Azara baryte which remains the major supplier of the commodity today. Thus, the production of baryte at Azara is very restricted and therefore, far from meeting the annual national demand. The neglect of mechanized mining possibly due to the prevailing harsh economic conditions gave room for the exploration of this baryte artesanally by the local inhabitants. The high demand for this commodity has made the activity thriving, providing a source of livelihood to the local communities around. On the other hand, poverty seems to be a major driving force since most people in these rural areas are poor and have no jobs. The main aim of this study is to highlight the environmental impact of artesanal mining of baryte in the Azara area through field observations, mappings and assessment.

Geology and mineralization: Geographically, the Benue trough is divided into the upper, middle and lower 


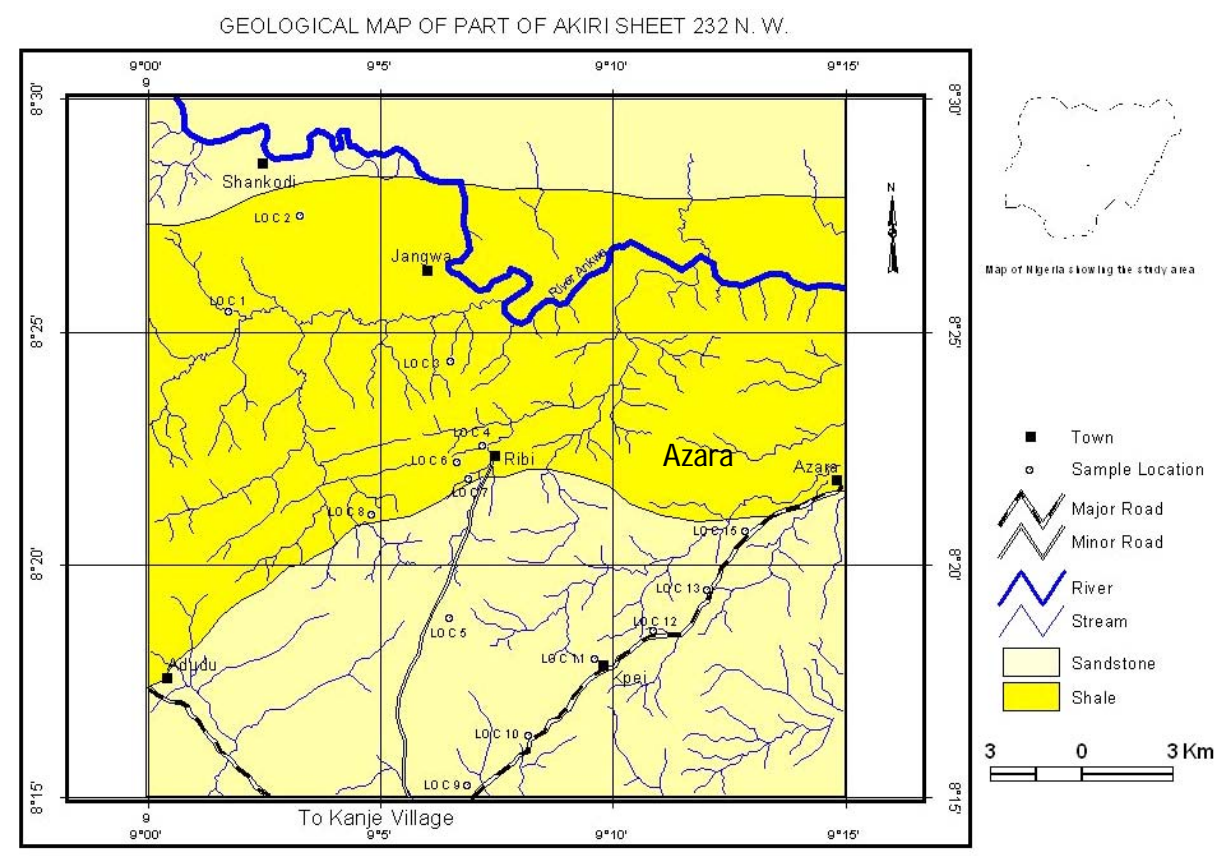

Fig. 3: Geological map of part of Akiri sheet 232 N.W

depositional sub-basins (Fig. 3). The area of study falls within the Middle Benue Trough and stratigraphically it is composed of continental and marine sediments, represented by sandstone, shale and the limestone of the Asu River Group (Offodile, 1976; Obaje, 1994). The succession upward is the Awe formation which consists of transitional sandstone, shale, siltstone and limestone and the fluviatile sandstone of the Keana Formation. The Azara area forms part of the northeastern limb of the Keana anticlinorium. Major baryte mineralization is associated with the mineralized hydrothermal vein that is a consequence of the tectonic rifting that led to the emplacement of the Benue Trough which was in part controlled by transcurrent fault activity (Benkhelil, 1989). These faultings are thought to have been responsible for creating pathways through which hydrothermal veins of possibly magmatic origin (Olade, 1976) or remobilized meteoric waters enriched in $\mathrm{Pb}, \mathrm{Zn}$ and $\mathrm{Na}$ percolated. Two sets of fractures were recognized in the Keana Azara area, the former of which are associated with the $\mathrm{Pb}-\mathrm{Zn}$ mineralization while the later was associated with the baryte mineralization (Offodile, 1976).

The baryte deposit in Azara occurs as hydrothermal veins within the cretaceous Keana sandstone of the middle Benue Trough. The defunct Nigerian Mining Corporation identified eighteen hydrothermal veins. The mineralized veins strike generally in the NE-SW, NW-SE and $\mathrm{E}-\mathrm{W}$ directions.
Uses and application of barytes: Baryte can be processed and used as a bleaching agent as a pigment or as extender for oil-drilling. It can also be used as inert filter in the manufacture of oil cloth, paper and plastics as well as a weighing material for textiles and leather industry. It is a major type of inert volume and weight filler in drilling mud in the oil industry in the chemical industry as a constituent in lithopone paint, in the gas and paper industry. It is also used to a small extent as a flux in brass melting when it acts mainly as a scavenger. The majority of the baryte produced in Nigeria are used as a heavy mud for oil-well drilling.

Economic benefits to local communities: Baryte exploitation in Azara area is serving as the second largest occupation after farming, by this it serves as a major source of employment to the teaming youths, most especially school leavers. The mining of baryte in Azara is season with its peak during the dry season (NovemberMay) when crops have been harvested (Fig. 4). People from far and near areas do migrate to this area during the dry season to engage in this activity. The activity is at low ebb during the rainy season when majority of the local miners shift to farming. Also contributory to this fact is that the dug out pits are easily flooded during the rains and could hamper effective work. Worthy of note is the fact that most of the nomadic Fulani cattle rearers have abandoned their main occupation and have engaged in this so-called lucrative business. 

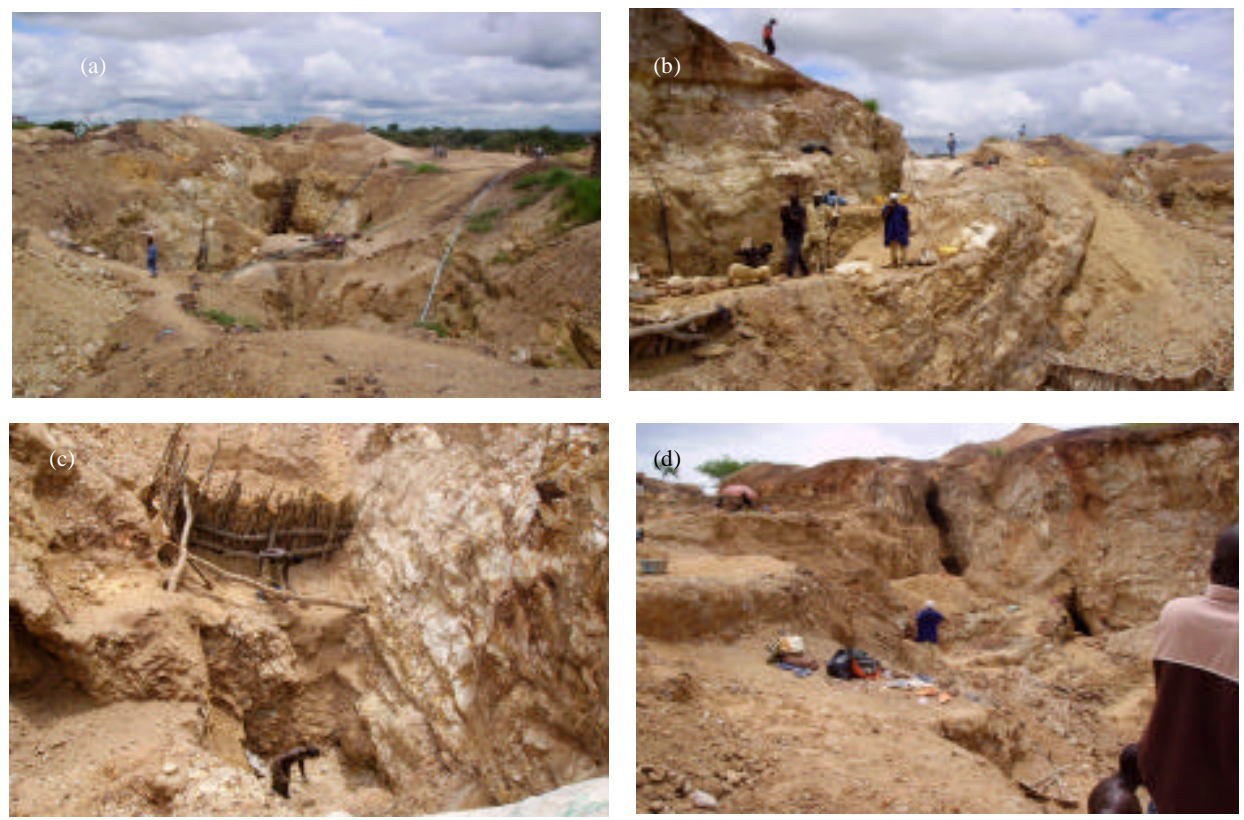

Fig. 4: Baryte mines showing different vein orientations at the Wuse mine site near Azara

The lifestyle of the local miners and the communities around Azara is being influenced by the new ways of life where money has become the only medium of transaction. Petit businesses such as food hawking, patent shops, provision stores, blacksmiths and beer parlors have sprung up thereby boosting the economy of the entire Azara mining settlements. The communities are economically emancipated to an extent. The movements of the baryte merchants in and out of Azara and their interactions with the local miners and the rural communities will increase the level of circulation of information and awareness.

As a result of the population growth in the area, the tax generation of the local community is enhanced. Power supply by means of generating sets within the mining camps is a noticeable infrastructure, though there is poor road network.

\section{RESULTS AND DISCUSSION}

Problems associated with the artesanal mining of baryte at Azara: The artesanal mining of barites in Azara is characterized by very poor safety and health standards resulting in numerous and often fatal accidents. The negative environmental impact is significant. This activity has left behind devastated landscape, exposed fertile lands, artificial dams, paddocks and abandoned ponds. Also it has endangered the life of both flora and fauna in the area. It is estimated that over 1,000 ha of arable land have been devastated by the artesanal mining activity. On the other hand because baryte with galena $(\mathrm{Pb}-\mathrm{Zn})$, the area is faced with potential danger of the release of $\mathrm{Pb}$ associated toxic elements ( $\mathrm{As}, \mathrm{Cd}, \mathrm{Sb}$, etc.) into the water systems. Trace elements study on the effects of the mineralizations within the middle Benue trough (Lar and Sallau, 2005) has shown that $\mathrm{Pb}, \mathrm{As}, \mathrm{Cd}$ and $\mathrm{Sb}$ etc. are released from $\mathrm{Pb}-\mathrm{Zn}$ mineralization into water bodies rendering such waters unsafe for human consumption.

The abandoned pits/ponds have now become dead traps. The investigations revealed that in the last two decades or so, quite a large number of livestock (cattle, sheep and goats etc.) were lost to these non-reclaimed mining ponds in the area. Some paddocks measured up to $100 \times 20 \times 50 \mathrm{~m}$ (i.e., length, breadth and depth). These ponds are however useful during the dry season where they are used as a source of water for irrigation, concentration of the mined ores, livestock and other domestic uses. The built up settlements resulting from the mining of barites are characterized by poor hygienic conditions and social vices like prostitution, drug abuse and organized crime are rampant. The spread of diseases such as HIV/AIDS could be rapid, since there is a high degree of the interaction of merchants from within and outside the community.

\section{CONCLUSION}

The artisanal mining of baryte at Azara, apart from farming provides another good source of income to hitherto poor stricken Azara communities (almost $80 \%$ of the total national demand of baryte comes from Azara. To sustain and increase production of baryte by these local miners, it is necessary that the contribution of these 
miners to solid mineral development is harnessed and safer alternatives be developed for its effective exploitation. These local miners could be supported through the acquisition of expensive mining equipment (which is beyond their reach) for leasing. In addition, the regulatory Government organ should provide extension services such as training on mining and environmental/ safety issues. Visibly, the drive to this highly risky method for mining the baryte by Azara people is poverty and lack of jobs. Government as the facilitator should boost their activity by making funds available to them in the form of soft loans to either individuals or groups. The negative environmental impact of the mining operations is great. Farmlands are destroyed and the abandoned mining pits/ponds from dead traps. To mitigate this, the Federal Ministry of Solid Mineral Development should ensure that laid down environmental laws are enforced. The built up settlements in Azara resulting from these mining operations are characterized by poor hygiene and social vices such as prostitution, drug abuse, child labor and organized crime. On the positive side, these abandoned ponds are a good source of water for agriculture (both for irrigation and fish farming) for livestock and other domestic uses. The water is also used for the benefication of the barite and associated ores.

\section{REFERENCES}

Aliyu, A.A., B.A. Aluko and K.O. Biliaminu, 1996. Priority Investment Projects in the Solid Minerals Sector. Raw Materials Research and Development Council, Abuja, pp: 67-73.
Benkhelil, J., 1989. The origin and evolution of the Cretaceous Benue Trough (Nigeria). J. Afr. Earth Sci., 8: $251-282$.

Lar, U.A. and A.K. Sallau, 2005. Trace element geochemistry of the Keana brines field middle Benue trough, Nigeria. Environ. Geochem. Health, 27: $331-339$.

Obaje, N.G., 1994. Coal petrography, microfossils and paleoenvironments of cretaceous coal measures in the middle Benue trough of Nigeria. Tuebinger Mikro-Palaeontologische Mitteilungen, 11: 165-165.

Obaje, N.G., U.A. Lar, A.I. Nzegbuna, A. Moumouni, M.S. Chaanda and N.G. Goki, 2006. Geology and Mineral Resources of Nasarawa State: An investosrs Guide. Elizabethan Publishers, Lagos.

Offodile, M.E., 1976. The Geology of the Middle Benue, Nigeria. Special Publication Paleontological Institute, University of Uppsala, pp: 1-166.

Offodile, M.E., 1989. A Review of the Geology of the Cretaceous Benue Valley. In: Geology of Nigeria, Kogbe, C.A. (Ed.). Elizabethan Publishing Co., Lagos.

Olade, M.A., 1976. On the origin of lead-zinc deposits in Nigeria's Benue rift (aulocogen): A re-interpretation. J. Mining Geol., 13: 20-27.

RMRDC, 1989. Technologies and machinery for processing mineral-based raw materials in Nigeria. Report by the Task Force Committee on Auditing of Indigenous and Emerging Technologies/Machinery, pp: 22-23. 